\title{
Different Injection Pressure on VCR Engine using Hibiscus Oil
}

\author{
K. Surendra Babu, B.Samuvel Michael, Anandhu Chandran, Jaimin Moncy, \\ Muflin Mon
}

\begin{abstract}
This present examination researches the presentation and outflow qualities distinctive infusion pressure on factor pressure proportion of a diesel motor utilizing Hibiscus oil. With different mixes of hibiscus seed oil, biodiesel and diesel mixes are set up to use as fuel on factor pressure proportion diesel motor. The outcomes indicated that decrease in brake warm effectiveness, nitric oxide and increment in brake explicit fuel utilization, carbon monoxide, hydrocarbon with Blends of hibiscus seed biodiesel mixes than flawless diesel. The minor departure from execution parameters like Brake explicit fuel utilization, Brake warm effectiveness and NO emanations Hydro carbon, Carbon Monoxide are surveyed and broke down.
\end{abstract}

Keywords: Hibiscus seed oil, Diesel, Injection nozzle.

\section{INTRODUCTION}

Increasing cost of the petroleum products and depleting petroleum reserves necessitates an intensive search for alternative fuels which can wholly or partially replace petro fuels[1]. The world is stood up to with a twin emergency of restricted inventory and the expanding cost of non-renewable energy sources[2]. The elective powers incorporate biodiesel, bioalcohol ( methanol, ethanol and butanol), synthetically put away power ( batteries and fuel cells), hydrogen, on-fossil methane, nonfossil flammable gas, vegetable oil, propane and different biomass sources should be figured to bring the applicable properties near customary energizes Hibiscus curcasis a local of tropical America, happening nearly all through India and in Andaman Islands[3]. It is proliferated effectively by seeds or cuttings and it develops quickly.

Revised Manuscript Received on December 30, 2019.

* Correspondence Author

K. Surendra babu*, Associate Professor, Department of Mechanical Engineering, AarupadaiVeedu Institute of Technology, Vinayaka Mission's Research Foundation, surendrababu@avit.ac.in

B. Samuel Michael, Research scholar, Department of Mechanical Engineering, AarupadaiVeedu Institute of Technology, VinayakaMission's Research Foundation, samuvalmichael@gmail.com

Anandhu chandran, UG Sholar, Department of Mechanical Engineering, AarupadaiVeedu Institute of Technology, Vinayaka Mission's Research Foundation.

Jaimin Moncy, UG Sholar, Department of Mechanical Engineering, AarupadaiVeedu Institute of Technology, Vinayaka Mission's Research Foundation.

Muflin Mon, UG Sholar, Department of Mechanical Engineering, AarupadaiVeedu Institute of Technology, Vinayaka Mission's Research Foundation.

(C) The Authors. Published by Blue Eyes Intelligence Engineering and Sciences Publication (BEIESP). This is an open access article under the CC BY-NC-ND license (http://creativecommons.org/licenses/by-nc-nd/4.0/)
The neem tree - Azadirachta indica originally a local of India, and is presently broadly conveyed all through the Indo-Malaysian district and is additionally found in tropical Africa. This investigation was planned for isolating seed oil from roan (Hibiscus sabdariffa) oilseeds utilizing utilization of dissolvable extraction technique. For hard core applications diesel motors have been utilized for quite a while during the previous decade just that it has gotten well known in light obligation application because of the higher eco-friendliness.

\section{PROPOSED METHOD USING HIBISCUS SEED OIL}

Oil seed crops are the main sources of nutritional, pharmaceutical and industrial appliances. The characteristics of oils from different sources depend on mainly on their compositions. To produce inexpensive oils low cost oil seed are needed. One of the alternative seed crop is hibiscus seed oil and its properties are shown in Table 1. The application of solvent extraction method is optimized for oil separation from hibiscus sabdariffa oil seeds for the extraction of oil. The seed oil investigation demonstrated the physical condition of the oil to be fluid/yellow-greenish in shading.

Table 1 Properties of hibiscus oil

\begin{tabular}{|c|c|c|}
\hline Properties & $\begin{array}{c}\text { Hibiscus } \\
\text { Oil }\end{array}$ & Diesel oil \\
\hline $\begin{array}{c}\text { Density at } 15^{\circ} \mathrm{C} \\
\left(\mathrm{kg} / \mathrm{m}^{3}\right)\end{array}$ & 746.69 & 843 \\
\hline $\begin{array}{c}\text { Viscosity At } 40^{\circ} \mathrm{C} \\
(\text { Centi Stroke) }\end{array}$ & 4.26 & 4.3 \\
\hline Flash point $\left({ }^{\circ} \mathrm{C}\right)$ & 182 & 47 \\
\hline Fire point $\left({ }^{\circ} \mathrm{C}\right)$ & 197 & 54 \\
\hline Cetane Number & 49 & $50-55$ \\
\hline $\begin{array}{c}\text { Calorific Value } \\
(\mathrm{kJ} / \mathrm{kg})\end{array}$ & 37178 & 44800 \\
\hline
\end{tabular}

\section{A. Test Set Up for Experiment:}

Test setup is shown in Fig 1 and Fig 2. A 3.5 kW, 1500 rpm, Kirloskar diesel engine is used in this assessment. Fuel use is evaluated utilizing optical sensor. A differential pressure transducer is utilized to quantify wind current rate. Motor is gotten together with a vortex current dynamometer to control motor torque through 
PC. Motor speed and weight are obliged by moving excitation current to whirl current dynamometer utilizing dynamometer controller. A piezoelectric weight transducer is familiar in motor chamber head with measure start pressure.

Sign from pressure transducer are sustained to charge intensifier. A high exactness wrench edge encoder is utilized to give signals for top perfectly connected with and wrench point. The sign from charge intensifier and wrench point encoder are given to information securing structure. An AVL fumes gas analyzer and AVL smoke meter are utilized to assess spread parameters and smoke control freely. Thermocouples (chrommelalumel) are utilized to check exhaust temperature, coolant temperature, and channel air temperature.

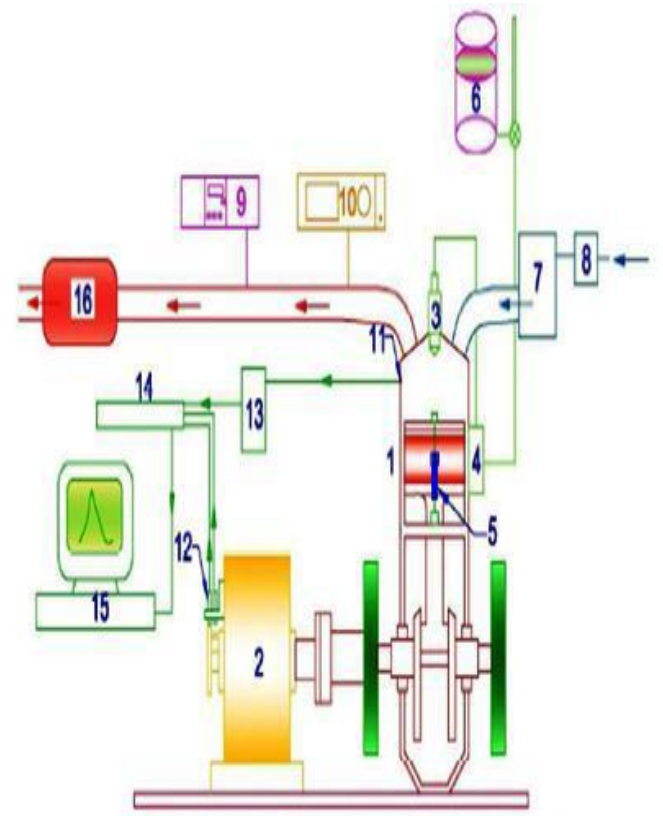

Fig. 1.Test Setup

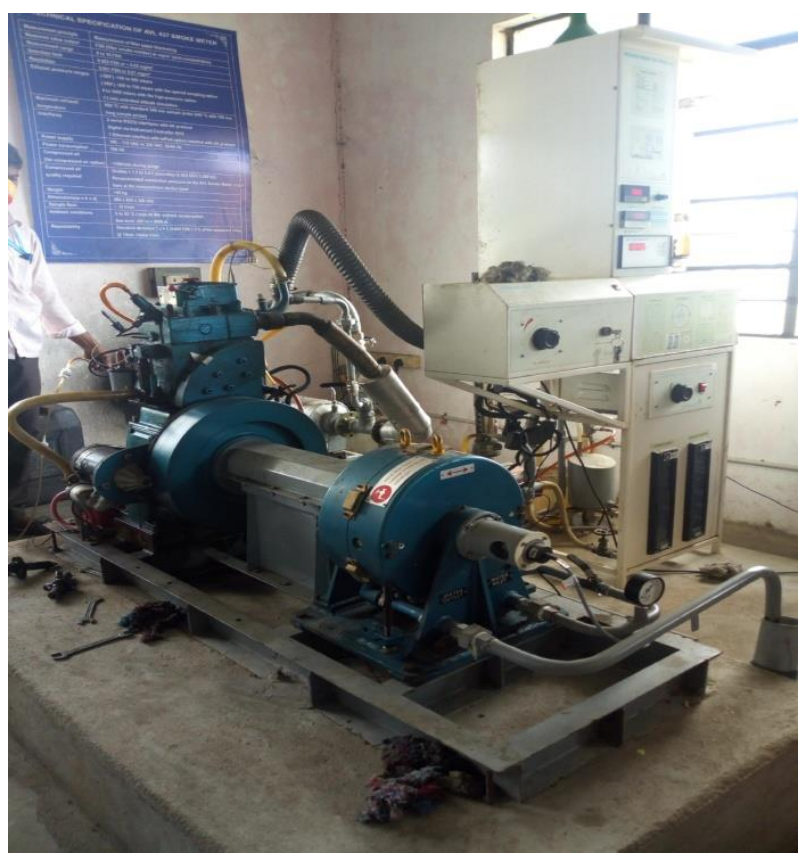

Fig. 2.VCR DIESEL ENGINE

\section{III.RESULTS AND DISCUSSIONS}

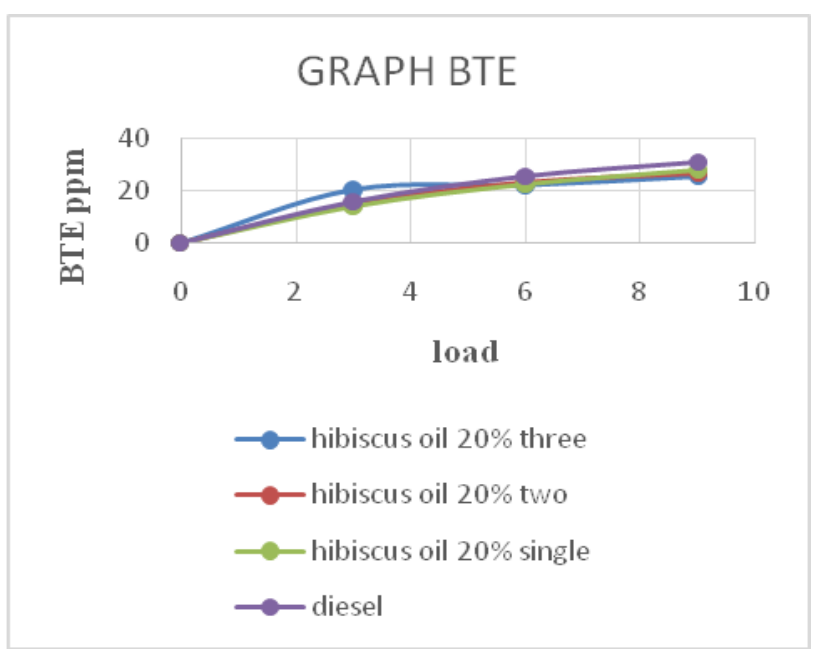

Fig. 3. BTE Graph

This BTE graph shown in Fig 3 shows two hole nozzle pressure of bio fuel Brake thermal efficiency is better than the diesel brake thermal efficiency

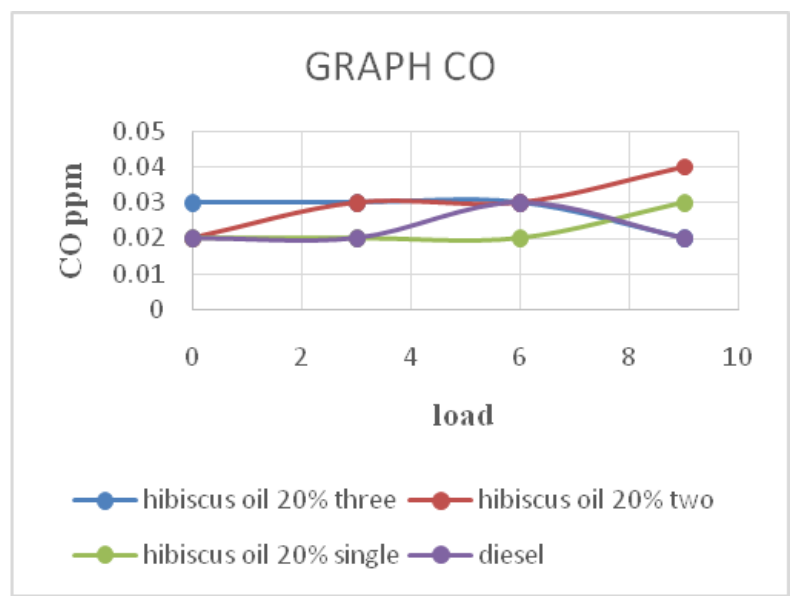

Fig. 4.GRAPH - CO

This CO graph in Gig 4 shows three hole nozzle pressure of carbon monoxide is better than the diesel carbon monoxide emissions

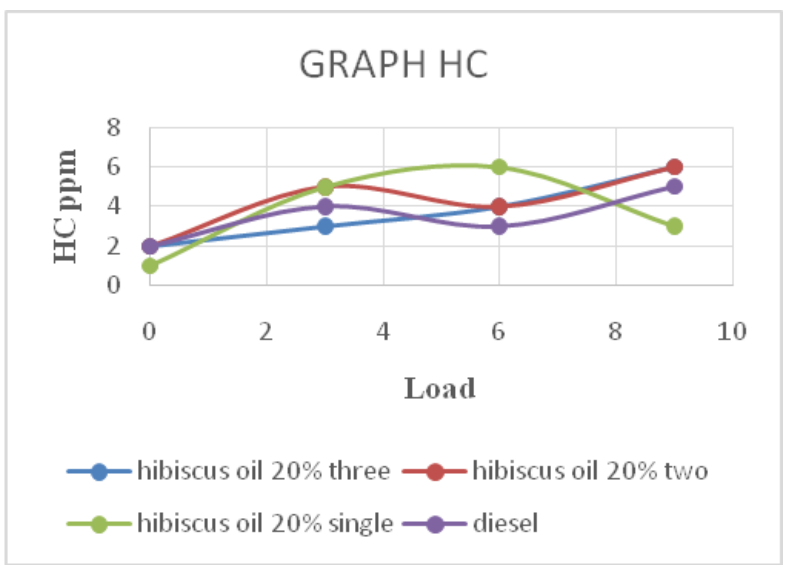

Fig. 5.HC Graph

Blue Eyes Intelligence Engineering \& Sciences Publication 
This HC graph shown in Fig 5 shows three hole nozzle pressure of hydro carbon emission is better than the diesel hydro carbon emissions

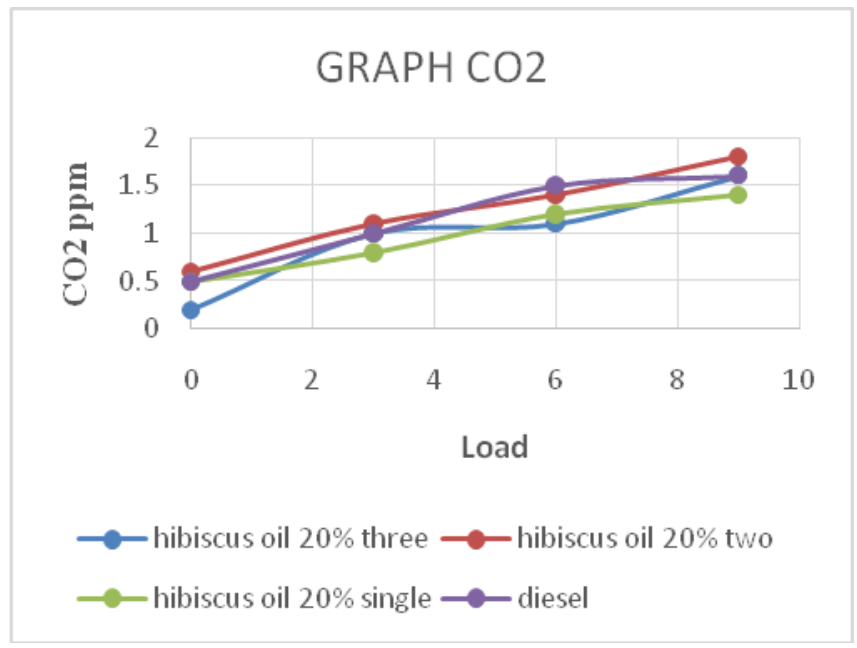

Fig. 6. Graph CO2

This CO2 graph in Fig 6 shows Single hole nozzle pressure of hydro carbon emission is better than the diesel hydro carbon emissions

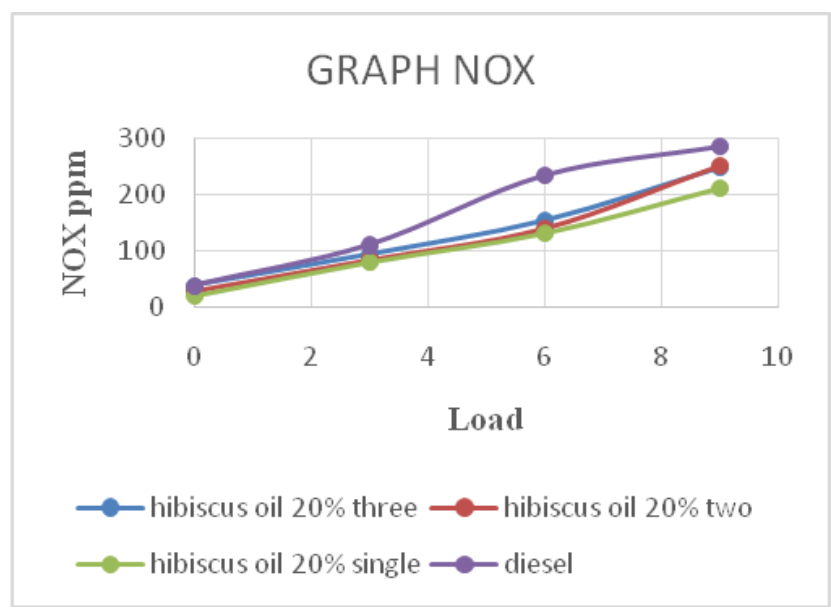

Fig. 7.NOX Graph

The NOX graph in Fig 7 shows Single hole nozzle pressure of hydro carbon emission is better than the diesel hydro carbon emissions

\section{CONCLUSION}

The BTE value of the two hole nozzle pressure of bio fuel Brake thermal efficiency is better than the diesel brake thermal efficiency.

The CO value of the three hole nozzle pressure of carbon monoxide is better than the diesel carbon monoxide emissions. The HC value of the three hole nozzle pressure of hydro carbon emission is better than the diesel hydro carbon emissions.

The CO2 value of the Single hole nozzle pressure of hydro carbon emission is better than the diesel hydro carbon emissions.
The NOX value of the Single hole nozzle pressure of hydro carbon emission is better than the diesel hydro carbon emissions.

\section{REFERENCES}

1. Agarwal D. and Agarwal A.K. "Performance and emission characteristics of Hibiscus seed oil (preheated and blends) in a direct injection compression ignition engine".International Journal of Applied Thermal. Engineering, (2007a) Vol.27, pp. 2314-2323

2. Narayana Reddy J. and Ramesh A. (2006) "parametric studies for improving the Performance of a hibiscus oil-fueled compression ignition engine", International Journal of Renewable Energy, Vol. 31. pp. 1994

3. Murugasen A., Umarani C., Subramanian R. and Neduchezhian N. "Bio diesel as an Alternative Fuel for Diesel Engine AReview".International Journal of Renewable and Sustainable Energy Review 2007.

4. Paramanik K. "Properties and use of hib"(2003)

5. Murugesan A. (2009) 'Experimental and theoretical Investigation of using Biodiesel in Diesel Engines: Ph.D., Thesis. Anna University, Chennai.

6. Senthil, K.Jayaraj S. (2009) "Performance and Emission Studies on a 4Stroke Diesel Engine using Methyl Ester of JME Oil with EGR", M.E. Thesis, Anna University, Chennai,

7. Sundarapandian and Devaradjane, "Performance and Emission Analysis of Bio Diesel Operated CI Engine", Journal of Engineering, Computing and Architecture.

8. John B. Heywood "Internal Combustion Engines"

9. Prabhu L., Satish Kumar S., Ramachandran S. and Rajan K. (2014), "Performance and emission characteristics of a diesel engine using nanoparticle as additive with biodiesel 250 ppm", International Journal of Applied Engineering Research. (ISSN 0973-4562) Vol. 9, No. 23 pp. 18759-18770, Research India Publications

\section{AUTHORS PROFILE}

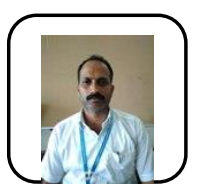

K. Surendra Babu, Associate Professor Department of Mechanical Engineering AarupadaiVeedu Institute of Technology Vinayaka Mission Research Foundation surendrababu@avit.ac.in.

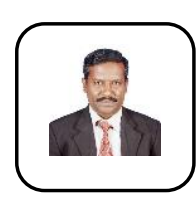

B.Samuel Michael, Research Scholar Department of Mechanical Engineering AarupadaiVeedu Institute of Technology Vinayaka Mission Research Foundation samuelmichael@avit.ac.in.

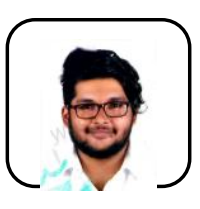

Anandhu chandran, UG Scholar Department of Mechanical Engineering AarupadaiVeedu Institute of Technology Vinayaka Mission Research Foundation

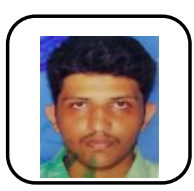

JaiminMonncy- UGScholar, Department of Mechanical Engineering AarupadaiVeedu Institute of Technology Vinayaka Mission Research Foundation

Muflin Mon A.K, UGScholar, Department of Mechanical Engineering AarupadaiVeedu Institute of Technology Vinayaka Mission Research Foundation. 